\title{
SISTER CHROMATID EXCHANGES IN SHEEP PERIPHERAL LYMPHOCYTES AFTER IN VITRO EXPOSURE TO METAL- CONTAINING EMISSION
}

\author{
J. DIANOVSKÝ, K. ŠIVIKOVÁ \\ Department of Veterinary Genetics, University of Veterinary Medicine. Košice. Slovak Republic
}

Received July: 27. 1998

Accepted August 29, 1998

\begin{abstract}
Dianovský J.. K. Siviková: Sister Chromatid Exchanges in Sheep Peripheral Lłmphocytes after in vitro Exposure to Metal-Containing Emission. Acta vet. Brno 1998. 67: 183-188.

Industrial pollutants, originated from aluminum processing factory, were tested for induction of sister chromatid exchanges (SCE). Experiments were carried out using sheep peripheral lymphocytes under in vitro assays. The emission tested contained $\mathrm{Al}, \mathrm{Cd}, \mathrm{As} . \mathrm{Mn}$. $\mathrm{Pb} . \mathrm{Cu}, \mathrm{Zn}, \mathrm{Fe}$. $\mathrm{Na} . \mathrm{Ca}$. and $\mathrm{Mg}$ : the majority of them in the form of sulphides, sulphates, oxides or fluorides. The emission was dissolved and neutralized according to a standard method. The mean of SCE was determined for three concentrations the emitted material $(30.60$ and $90 \mu \mathrm{g} / \mathrm{ml})$ with presence and absence of the metabolic activation ( $\mathrm{S} 9 \mathrm{mix}$ ). The lowest concentration used corresponded to daily oral intake by sheep grazing on contaminated area. Results from both assays were similar; the significant increase in SCE was observed at the concentration of $60 \mu \mathrm{g} / \mathrm{ml}(\mathrm{p}<0.01)$. More conspicuous results were observed without of S 9 . No significant decrease in the induction of proliferation index (PI) was found. A dose related effect was observed for SCE induction but not for inhibition of proliferation kinetics.
\end{abstract}

Pasture contaminants, genotoxicity, metabolic activation, in vitro

There are many genotoxic effects caused by environmental exposure to metals and nonmetallic compounds. Almost all the metals and non-metallic compounds present in the emission tested have been reported to have some limited or positive genotoxic effects in different assays.

Aluminum $(\mathrm{Al})$ is considered to be cytotoxic due its interference with the GTP-ase cycles (E x le y and B i r c h a 11 1993). It had also limited cancerogenic effect on chronically exposed workers in the aluminum reduction industry (Pe a rs on et al. 1993). The majority of in vivo and in vitro cytogenetic assays performed to evaluate clastogenic potency of cadmium (Cd) yielded negative results ( $L$ é o $n$ a $r d$ and B e r $n$ a $r d$ 1993); however, cadmium chloride induced DNA single-strand breaks, DNA protein cross-links, and chromosomal aberrations in V79 chinese hamster cells (O c h i et al. 1984). Cadmium sulphate exhibited also a limited teratogenic effect inducing developmental abnormalities in the skeleton of mice ( $\mathrm{M}$ u r a t a e t al. 1993).

Arsenic (As) is one of the few identified human carcinogens that has been shown to cause cancer in rodents (M o o r e t al. 1997). Its genotoxic effect is documented by numerous data about its clastogenic effect in different assays, e.g. SCE in human peripheral lymphocytes by an in vitro assay (A $\mathrm{n}$ d e r s e $\mathrm{n}$ e $\mathrm{t}$ al. 1982); micronuclei ( $\mathrm{MN}$ ) in Chinese hamster ovary cells (W a n g et al. 1997); chromosome aberrations (CA) in cultured human lymphocytes ( $\mathrm{S}$ we in s 1983). Lead $(\mathrm{Pb})$, copper $(\mathrm{Cu})$, and iron $(\mathrm{Fe})$ as well as other metal 
(II) ions - zinc $(\mathrm{Zn})$ and cobalt $(\mathrm{Co})$ are also considered to be potentially genotoxic due to inhibition of nucleotide excision repair ( $\mathrm{C}$ a l s o u e $\mathrm{t}$ al. 1996).

On the other hand. zinc ( $\mathrm{Zn})$ as well as magnesium $(\mathrm{Mg})$ are known to act as protective agents against the genotoxic damage ( $\mathrm{S} \mathrm{m}$ i th e t al. 1994: L i t t le fie ld e t a l. 1994).

Fluoride $\left(\mathrm{F}^{-}\right)$is not mutagenic in standard bacterial tests, but it produces chromosome aberrations and gene mutations in cultured mammalian cells ( $\mathrm{Z}$ e i g e r e $\mathrm{t}$ a 1. 1993). In vilo cytogenetic studies in mice did not confirm the clastogenicity of fluoride reported above (Zei ge r e t al. 1994).

Genotoxicity estimation in complex mixtures meets with serious problem because they might contain hundreds or thousands of chemicals. and many of them cannot be identified and quantified by current analytical capabilities ( $\mathrm{H} \mathrm{o} \mathrm{u} \mathrm{k}$ and $\mathrm{W}$ a t e r s 1996). The present study will allow us to compare the effect of exposure to metal containing emission on sheep peripheral

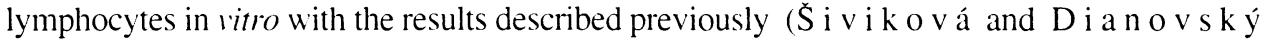
1995).

\section{Materials and Methods}

\section{Emission}

The industrial emission originated from aluminum reduction industry was collected as surface scales from meadow's nearby the factory. Pollutants were dissolved by a standard method using the mixture of concentrated nitric $\left(\mathrm{HNO}_{3}\right)$ and hydrochloric $(\mathrm{HCl})$ acid $1: 3$, neutralized by natrium hydroxide $(1 \mathrm{~N} \mathrm{NaOH})$ and filtered. The concentration of dissolved metals and non-metallic compounds was determined by spectrophotometric analysis (Perkin-Elmer: Dept. of Internal Diseases, University of Veterinary Medicine in Košice). Per cent content of the emission is seen in Table 1. The daily intake of emission by sheep grazing on contaminated area $(30 \mathrm{mg} / \mathrm{kg} \mathrm{bm})$ as well as its arithmetic multiples $(60$ and $90 \mu \mathrm{g} / \mathrm{ml})$. were used in our experiments. The multiple next to the highest one used $(120 \mu \mathrm{g} / \mathrm{ml})$ was cytotoxic. because more than $50 \%$ reduction of the mitotic index (MI) in comparison with the control level. All concentrations were applied at same volume ( $0.5 \%$ of total cultivation volume) supplemented with sterile phosphate-buffer saline (PBS), pH 7.2.

Mitomycin C (MMC. Sigma. St. Louis. MO. USA. $4 \mu \mathrm{M}$ ) and cyclophosphamide (CPA. Jenapharm, Ankerwerk. Rudolstadt. Germany. $4 \mu \mathrm{g} / \mathrm{ml}$ ) were used as positive control agents in assay's with absence and in the presence of the metabolic activation ( $\mathrm{S} 9 \mathrm{mix})$.

Table 1

\section{Composition of emission}

\begin{tabular}{|l|l|l|l|}
\hline Element & Percent & Element & Percent \\
\hline $\mathrm{Al}$. & 4.3 & $\mathrm{Zn}$ & 0.036 \\
$\mathrm{Cd}$ & 0.00475 & $\mathrm{Fe}$ & 1.54 \\
$\mathrm{As}$ & 0.00775 & $\mathrm{Na}$ & 1.09 \\
$\mathrm{Mn}$ & 0.0626 & $\mathrm{Ca}$ & 0.234 \\
$\mathrm{~Pb}$ & 0.1398 & $\mathrm{Mg}$ & 0.049 \\
$\mathrm{Cu}$ & 0.0099 & $\mathrm{~F}$ & 20.0 \\
\hline
\end{tabular}

Each of elements was present in the ionic form as a sulphide. sulphate. or oxide and fluoride

Cultivation of cells

The general approach for SCE estimation comprises in vitro assays with and without metabolic activation. The experiments were carried out using heparinized blood samples from two healthy donors of both sexes. one year old. kept and fed under standard conditions.

Samples $(0.5 \mathrm{~mL})$ were cultured in $5 \mathrm{~mL}$ of RPMI 1640 medium supplemented with L-glutamine. $15 \mathrm{M} / 1 \mathrm{HEPES}$ (Sigma. St. Louis. MO. USA). $15 \%$ foetal calf serum. antibiotics (penicillin $250 \mathrm{U} / \mathrm{ml}$ and streptomycin $250 \mu \mathrm{g} / \mathrm{ml}$ ). and phytohaemagglutinin (PHA, $180 \mu \mathrm{g} / \mathrm{ml}$. Welcome. Darford. England) at $38^{\circ} \mathrm{C}$ for $72 \mathrm{~h}$. 
Bromdeoxyuridine (BrdUrd. Sigma) was added to all cultures at a final dose of $8 \mu \mathrm{g} / \mathrm{ml} 48 \mathrm{~h}$ before the harvest. The influence of different doses of emission in the experiment without metabolic activation took place lasted $24 \mathrm{~h}$ of cultivation. To achieve cytostatic block. colchicine (Merck. Darmstadt. Germany) was added at a concentration of $5 \mu \mathrm{g} / \mathrm{ml} 2 \mathrm{~h}$ before the harvest in both assays.

\section{Metabolic activation}

Freshly prepared S9 fraction (10\% of the culture volume) from Aroclor 1254 (Supelco. Bellefonte. PA. USA) induced male mice was prepared according to the method of Maron and Ames (1983) and was applied to all control and experimental cultures. Glucoso-6-phosphate (Aldrich, Milwaukee. WI. USA) and NADP (Sigma. St. Louis, MO. USA) were used as cofactors. Cultures enriched with S $9 \mathrm{mix}$ were treated by the emission for $2 \mathrm{~h}$, and then the cells were rewashed twice and replaced to the fresh culture medium.

\section{Evaluation and s tatistic methods}

Chromosome preparations were obtained by the standard method. Slides were stained with FPG technique to differentiate sister chromatides and cell cycles ( $\mathrm{P}$ e r r y and W o l f f 1974) for the SCE delumination and cell cycle kinetics. Fifty differentially stained metaphases per donor and concentration were examined for the SCE and 100 metaphases for determination of $\mathrm{M}_{1} . \mathrm{M}_{2}$ and $\mathrm{M}_{3+}$ mitotic divisions. The proliferation indices (PI) were calculated according to $\mathrm{L} \mathrm{a} \mathrm{m}$ be $\mathrm{rt}$ i e t al. (1983).

Statistical analysis of results was performed using a simple analysis of variance (ANOVA). Then Student's t-test was applied to evaluate the SCEs significance for the treated and untreated groups and also for estimation of the cell cycle delay.

\section{Results}

The frequencies of SCE as well as proliferation kinetics induced by emission in the in vitro experiments both with and without of $\mathrm{S} 9 \mathrm{mix}$ metabolic activation are shown in Table 2. A dose dependence of the induced changes was seen in both the assays. Positive clastogenic effect started at concentration of $60 \mu \mathrm{g} / \mathrm{ml}(\mathrm{p}<0.01)$ in both experiments, i.e.with and without metabolic activation. The highest concentrations tested $(90 \mu \mathrm{g} / \mathrm{ml})$ was also statistically significant. The results performed the level $p<0.001$ according to the Student's t-test. More conspicuous increase in SCE frequency was observed in the latter assay, i.e. without metabolic activation.

Table 2

Frequency of SCEs and proliferation indices in sheep cultured peripheral lymphocytes exposed to the industrial emission with and without of $\mathrm{S} 9$ mix metabolic activation

\begin{tabular}{|c|c|c|c|c|c|}
\hline Treatment & SCE / cell & $\mathrm{PI}$ & Treatment & SCE / cell & PI \\
\hline $\begin{array}{l}\text { Control } \\
\text { (PBS) } \\
\text { Emission }(\mu \mathrm{g} / \mathrm{ml}) \\
24 \text { h }(-\mathrm{S} 9) \\
30 \\
60 \\
90\end{array}$ & $\begin{array}{l}6.72 \pm 2.12 \\
6.52 \pm 1.44^{*} \\
7.65 \pm 1.93 * * \\
9.00 \pm 3.05 * * *\end{array}$ & $\begin{array}{l}1.56^{\mathrm{a}} \\
1.48^{\mathrm{a}} \\
1.50^{\mathrm{a}}\end{array}$ & $\begin{array}{l}\text { Control } \\
\text { (PBS) } \\
\text { Emission }(\mu \mathrm{g} / \mathrm{ml}) \\
2 \mathrm{~h}(+\mathrm{S} 9) \\
30 \\
60 \\
90\end{array}$ & $\begin{array}{l}6.56 \pm 1.54 \\
7.71 \pm 1.77 \\
8.66 \pm 2.21\end{array}$ & $\begin{array}{l}1.52^{\mathrm{a}} \\
1.54^{\mathrm{a}} \\
1.46^{\mathrm{a}}\end{array}$ \\
\hline $\begin{array}{l}\text { Positive } \\
\text { Control } \\
0.4 \mu \mathrm{M}, \mathrm{MMC} \\
\end{array}$ & $9.60 \pm 3.05 * * *$ & $1.46^{\mathrm{a}}$ & $\begin{array}{l}\text { Positive } \\
\text { Control } \\
4 \mu \mathrm{g} / \mathrm{ml} \text {. } \\
\text { cyclophosphamid }\end{array}$ & $10.90 \pm 3.25 * *$ & $1.44^{\mathrm{a}}$ \\
\hline
\end{tabular}

A total of 100 second - division metaphases of each group were analysed for SCE.

$\because$ * **** statistical significant data $(p<0.05: p<0.01: p<0.001$. ANOVA, Student's t-test)

a - no statistical significance according to previous or $\chi^{2}$ test

PI - Proliferation index 
A weak decrease in proliferation indices without dose dependence or statistical significance were also observed ( Table 2). In both experiments, the proportion of $M_{1}, M_{2}$ and $M_{3+}$ were not significantly different from those seen in control groups. The difference in induced mitotic delay between control and experimental groups reflected by PI was thus not verified.

Kinetics of results in the absence of S 9 is seen in Figure 1.

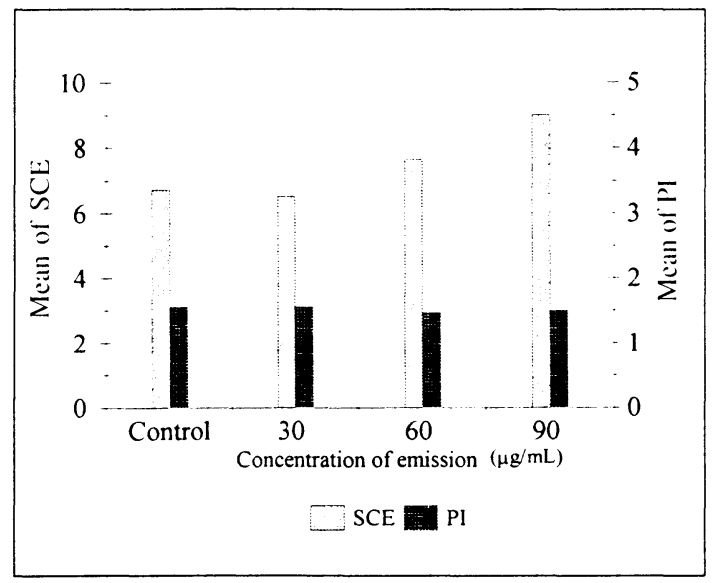

Fig. 1. Kinetics of SCE induced by emission in sheep peripheral lymphocy tes without metabolic activation.

\section{Discussion}

Induction of sister chromatid exchanges represents a sensitive cytogenetic endpoint for detection of genotoxic activity of environmental mutagens and carcinogens (WHO 1993).

We found dose-related SCE increases in both in vitro assays. On the basis of more conspicuous results in the assay without $\mathrm{S} 9$ metabolic activation we can conclude that the metabolic capacity of self-activating erythrocyte enzymes was sufficient for such type of experiments ( $\mathrm{C}$ a n telli-Forti et al. 1988). On the other hand the 24-h exposure to the emitted material resulted in weak reduction of lymphocyte proliferation. The results were not statistically significant, and were not related to the dose used.

Various methods can be used to evaluate the in vivo and in vitro processes such as those described by C a r d o t and B e y s s a c (1993). We shall focus on the correlation which offers the greatest scope of matters studied, namely one-to-one relationship between the in vivo input and in vitro dissolution rates. This procedure has been used for a basic estimation of dose in the in vitro test. The basic dose $30 \mu \mathrm{g} / \mathrm{ml}$, exibiting a weak cytotoxic effect in the chronic oral experiment in sheep ( $\breve{S}$ i v i k o v á and D i a n o v s k ý 1995), had no significant genotoxic or cytotoxic effect. The arithmetic increase of the doses tested led to a dose related response expressed in the SCE induction without any cytotoxic effect. This fact predicts the highest sensitivity for the in vitro assay. Because a linear relationship between the frequencies of SCE and gene mutations was suggested ( $\mathrm{C}$ a $\mathrm{rr}$ a $\mathrm{n}$ o and Th o m p s o n 1982), induced point mutations and the related changes might cause the genotoxic effect of the emission. Cumulative genotoxicity of industrial pollutants or other environmental factors is detectable in veterinary practice using different indirect criteria (W u r g l e r and $\mathrm{K} \mathrm{ra} \mathrm{m} \mathrm{me} \mathrm{r} \mathrm{s} \mathrm{1992).} \mathrm{They} \mathrm{include} \mathrm{the} \mathrm{resistance} \mathrm{of} \mathrm{insect} \mathrm{(especially}$ wormflies or ticks) to insecticides; bacterial resistance to currently used antibiotics; increased frequency of cancer in different animal species living in contaminated areas; 
reproductive errors or increase in developmental abnormalities in newborns. In spite of numerous resources dealing with cancerogenicity, reproductive disturbances, mutagenic effect and other related changes of majority of metals and non-metallic compounds obtained in the emission, we did not confirm them because of incompleteness of data. Local veterinarians are obliged to keep evidence of developmental defects in newborns only of economically important species. According to reports given to respective authorities (Center for Genetic Prevention) in 1995, the frequency of developmental defects in cattle (axial skeleton and body cavities, especially) was remarkably higher, namely 14 in the affected district Žiar n/ Hronom, in comparison with the adjacent districts - 6 in Zvolen, or 2 in Lučenec. Total percentage of developmental defects in the district represented $9.58 \%$ of all developmental disorders reported in cattle in the middle Slovakia territory at the given time.

In conclusion we demonstrated the genotoxic effect of metal emission in cultured sheep peripheral lymphocytes.

\section{Sesterské chromatidové výmeny indukované in vitro $\mathrm{v}$ ovčích periférnych lymfocytoch kovy obsahujúcou priemyslovou emisiou}

Priemyslová emisia pochádzajúca zo závodu na výrobu hliníka bola hodnotená testom na indukciu sesterských chromatidových výmen (SCE). Pokusy sa uskutočnili v in vitro podmienkach s použitím periférnych lymfocytotov oviec. Testovaná emisia obsahovala $\mathrm{Al}$, $\mathrm{Cd}, \mathrm{As}, \mathrm{Mn}, \mathrm{Pb}, \mathrm{Cu}, \mathrm{Zn}, \mathrm{Fe}, \mathrm{Na}, \mathrm{Ca}$ a $\mathrm{Mg}$, pričom väčšina prvkov bola zastúpená sulfidmi, sulfátmi, oxidmi alebo fluoridmi. Po rozpustení a neutralizácii bola frekvencia SCE stanovená pre tri základné koncentrácie $(30.60$ a $90 \mu \mathrm{g} / \mathrm{ml}) \mathrm{s}$ metabolickou aktiváciou S9 mix frakciou, i bez nej. Najnižšia hodnotená koncentrácia zodpovedala dennému orálnemu príjmu emisie pre ovce pasúce sa $\mathrm{v}$ kontaminovanom prostredí. Výsledky získané $v$ obidvoch formách testu boli podobné, štatisticky významné zvýšenie SCE začínalo pri koncentrácii $60 \mu \mathrm{g} / \mathrm{ml}(\mathrm{p}<0.01)$. Výraznejšie výsledky boli zaznamenané $\mathrm{v}$ teste bez metabolickej aktivácie. Nezistilo sa však zniženie proliferačného indexu (PI) hodnotených buniek. Pri hodnotení SCE sa tiež pre obidve formy testu zistila dávková závislosté, čo svedčí o genotoxickom pôsobení emisie. Ako nepriamy dôkaz spomenutých genotoxických účinkov môže slúžit aj zvýšená frekvencia vývojových chýb u hovädzieho dobytka $v$ kontaminovanej oblasti v porovnaní so susednými okresmi.

\section{Acknowledgements}

This work was supported by the Ministry of Education and Science of the Slovak Republic (Grant No. 1/5150/98).

\section{References}

ANDERSEN. O.. WULF. H. C.. RØNE. M.. NORDBERG. G. F. 1982: Effects of metals on sister chromatid exchange in human lymphocytes and chinese hamster V79-E cells Prevention of occupational cancer International symposium .International labour service. Geneva. Occupational Safety Health Series. No 46: 49150

CALSOU.P.. FRIT. P.. BOZZATO. P. SALLES. B. 1996: Negative interference of metal (II) ions with nucleotide excision repair in human cells free extracts. Carcinogenesis 17: 2779-2782

CANTELLI - FORTI. G.. PAVLINI. M.. HRELIA. P.. CORSI. C.. BRONCETTI. G. 1988: Genetic activity of 2 -aminofluoren in the Salmonella erythrocyte mutagenicity assay. Mutat. Res. 196: 83

CARDOT. J. M.. BEYSSAC. E. 1993: In vitro/in vivo correlations: Scientific implications and standardization. Eur. J. Drug Metab. Pharm. 18: 113-120

CARRANO. A. V.. THOMPSON. L. H., STETKA. L. G.. MINKLER. J. L., MAZRIMAS. J. A.. FOG. S. 1979: DNA crosslinking, sister chromatid exchange and specific-locus mutations. Mutat. Res. 63: 175-188

CHAN- PO. C.. HUFF, J.1997: Arsenic carcinogenesis in animals and humans: mechanistic, and epidemiological evidence. Environ. Carcino. \& Ecotox. Revs. C 15 (2): 83-122 
EXLEY.CH.. BIRCHALL. J. D. 1993: The cellular toxicity of aluminium. J. theor. Biol. 159: 83-98

HARTWIG, A. 1994: Role of DNA repair inhibition in lead- and cadmium-induced genotoxicity: A revue. Environ. Health Perspect. 102, Suppl. 3: $45-50$

HOUK. V. S.. WATERS .M. D. 1996: Genetic toxicology and risk assessment of complex environmental mixtures. Drug Chem. Toxicol. 19: 187-219

LAMBERTI. L.. PONZETTO. B. P., ARDITO. G.. 1983: Cell kinetics and sister chromatid exchange frequency in human lymphocytes. Mutat. Res. 120: 193-199

LÉONARD. A.. BERNARD. A. 1993: Biomonitoring exposure to metal compounds with carcinogenic properties. Environ. Health Perspect. 101, Suppl. 3: 127-133

LITTLEFIELD. N. A.. HASS. B. S.. JAMES. J. S. POIRER. L. A. 1994: Protective effect of magnesium on DNA strand breaks induced by nickel and cadmium. Cell Biol. Toxicol. 10: 127-135

MARON. D. M.. AMES. B. N. 1983: Revised methods for the Salmonella mutagenicity test. Mutat. Res. 113: $173-$ 215

MOORE. M. M.. HARRINGTONBROCK. K. DOERR, C. L. 1997: Relative genotoxic potency of arsenic and its methylated metabolites. Mutat. Res. 386: 279-290

MURATA. M.. TAKIG.AWA. H.. SAKAMOTO. H. 1993: Teratogenic effect of noise and cadmium: Does noise have teratogenic potential? J. Toxicol. Environ. Health 39: $237-245$

OCHI. T.. MOGI. M.. WATANABE. N.. OHSAWA. M. 1984: Induction of chromosomal aberrations in cultured Chinese hamster cells by short-term treatment with cadmium chloride. Mutat. Res. 137: 103-109

PEARSON. R. J. C.. B.TTTIGELLI. M. C.. GAMBLE. J. T. 1993: Mortality from working in the aluminum reduction industry. Environ. Res. 61: 19-24

PERRY. P.. WOLFF. S. 1974: New Giemsa methods for differential staining of sister Chromatids. Nature 251: $156-158$

SMITH. J. B.. SMITH. B.. PIJUAN, V.. ZHUANG. Y.. CHEN. Y. CH. 1994: Transmembranal signals on protooncogene induction evoked by carcinogenic metals and prevented by zinc. Environ. Health Perspect. 102, Suppl. 3: $181-189$

SWEINS. A. 1983: Protective effect of selenium against arsenic induced chromosomal damage in cultured human lymphocytes. Hereditas 98: 249-252

SIVIKOVÁ, K.. DIANOVSKYY.J. 1995: Sister-chromatid exchanges after exposure to metalcontaining emissions. Mutat. Res. 327: 17-22

WANG, T. S., SHU. Y. F., LIU. Y. C.. YAN, K. Y., HUANG, H. 1997: Glutathion peroxidase and catalase modulate the genotoxicity of arsenite. Toxicology 121: 229- 237

WHO 1993: Biomarkers and risk assessment: Concept and principles. IPCS Environmental Health Criteria 155. WHO. Geneva. $87 \mathrm{p}$.

WURGLER, E. F., KRAMMERS. P. G. 1992: Environmental effect of genotoxins (eco-genotoxicology). Mutagenesis 7: $321-327$

ZEIGER, E., SHELBY.M. D. , WITT. K. L. 1993: Genetic toxicity of fluoride. Environ. Mol. Mutagen. 21: $309-$ 318

ZEIGER, E., Gulati. K. D., KAUR, P., MOhamed, A. H., ReVAZOVA. J., DEATON. T. G. 1993: Cytogenetic studies of sodium fluoride in mice. Mutagenesis 9: 467-471 